\title{
The DiabCare Asia 2008 study - Outcomes on control and complications of type 2 diabetic patients in Indonesia
}

\author{
Pradana Soewondo, ${ }^{1}$ Sidartawan Soegondo, ${ }^{1}$ Ketut Suastika, ${ }^{2}$ Agung Pranoto, ${ }^{3}$ Djoko W. Soeatmadji, ${ }^{4}$ Askandar \\ Tjokroprawiro ${ }^{5}$ \\ ${ }^{1}$ Division of Endocrinology, Department of Internal Medicine, Faculty of Medicine, University of Indonesia, Cipto Mangunkusumo \\ Hospital, Jakarta, Indonesia \\ ${ }^{2}$ Faculty of Medicine, Udayana University, Sanglah Hospital, Denpasar, Bali, Indonesia \\ ${ }^{3}$ Diabetes and Nutrition Center, Division of Endocrinology Metabolism, Department of Internal Medicine, RSU dr. Soetomo \\ General Hospital Medical Faculty of Airlangga University, Indonesia \\ ${ }^{4}$ Saiful Anwar Hospital, Malang, Indonesia \\ ${ }^{5}$ Surabaya Diabetes and Nutrition Center dr. SoetomoTeaching Hospital, Facultyof Medicine Airlangga University, Indonesia
}

\begin{abstract}
Abstrak
Tujuan: Mengumpulkan informasi mengenai penanganan dan komplikasi diabetes, serta kesadaran pengendalian diri sendiri penderita diabetes di Indonesia. Studi ini juga mengevaluasi perspektif dokter, aspek psikologis, dan kualitas hidup pasien.

Metode: Studi non-intervensi, potong lintang, merekrut 1832 pasien dari pusat kesehatan sekunder dan tersier di Indonesia. Data mengenai demografi, riwayat medis, faktor resiko, dan laporan pemeriksaan klinis termasuk laboratorium dikumpulkan dari rekam medis pasien. Sampel darah dikumpulkan untuk pengukuran HbA1c yang tersentralisasi.

Hasil: Di antara 1832 pasien, 1785 individu memenuhi syarat untuk dianalisis. Rata-rata usia adalah 58,9+9,6 tahun. Lamanya menderita diabetes 8,5+7,0 tahun. Mayoritas pasien (97,5\%) menderita diabetes tipe 2.67,9\% pasien memiliki kontrol diabetes yang buruk (A1c: 8,1 \pm 2,0\%). 47,2\% pasien memiliki kadar Glukosa Plasma Puasa $>130$

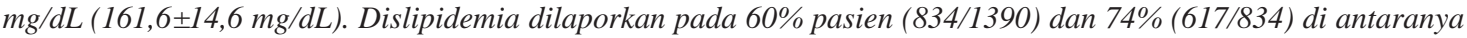
mendapatkan obat hipolipidemik. Neuropati merupakan komplikasi paling umum (67.2\%); komplikasi diabetes lainnya antara lain: katarak: 14.5\% Retinopati diabetik non-proliferatif: 8.3\%, kreatinin serum>2 mg/dl: 3.6\%, ulkus yang sudah sembuh: 3.8\%, angina pectoris 9.9\% dan stroke 5.6\%. Sekitar $81.3 \%$ pasien menerima terapi obat hipoglikemik oral $(\mathrm{OHO}$ ) ( \pm insulin), 37,7\% pasien menerima terapi insulin ( $\pm \mathrm{OHO}$ ). Penggunaan biguanide diikuti oleh sulfonylurea. Mayoritas pasien menggunakan insulin manusia 73,2\%, regimen premiks 58,5\%, insulin analog 24,9\%. Mayoritas respon indeks kesehatan WHO-5 jatuh dalam teritori positif.
\end{abstract}

Kesimpulan: Kontrol glikemik yang buruk pada mayoritas pasien diabetes perlu diperhatikan. Terdapat kebutuhan untuk penyesuaian terapi dari sebagian besar pasien menuju terapi farmakologis yang lebih intensif dan pendekatan multidisipliner harus digunakan. Temuan studi ini perlu dikomunikasikan kepada pembuat kebijakan dan dokter untuk membantu mereka memberikan perawatan kesehatan dan fasilitas yang baik. (Med J Indones 2010; 19:235-44)

\begin{abstract}
Aim: To collect information on diabetes management, diabetes complications, and awareness of self-control in diabetic population of the country. This study also evaluated the physician perspectives, psychological aspects, and quality of life of diabetic patients.

Methods: This was a non-interventional, cross-sectional study, which recruited 1832 patients from secondary and tertiary medical centers across Indonesia. Data on demography, medical history, risk factors and clinical examination reports including laboratory assessments were collected from medical records of patients. Blood samples of all patients were collected for centralized $\mathrm{HbA} 1 \mathrm{c}$ measurements.

Results: Among 1832 patients, 1785 individuals were eligible for analysis. The mean age of the patients was 58.9+9.6 years. The mean duration of diabetes was $8.5 \pm 7.0$ years. Majority $(97.5 \%)$ of the patients had type 2 diabetes. $67.9 \%$ had poor control of diabetes (A1c:8.1 $\pm 2.0 \%$ ). 47.2\% had FPG $>130 \mathrm{mg} / \mathrm{dL}(161.6 \pm 14.6 \mathrm{mg} / \mathrm{dL})$. Dyslipidemia was reported in $60 \%(834 / 1390)$ and $74 \%(617 / 834)$ of those received lipid lowering treatment. Neuropathy was most common complication (63.5\%); other complications were: Diabetic retinopathy $42 \%$, nephropathy $7.3 \%$, severe late complications $16.9 \%$, macrovascular complications $16 \%$, microvascular complications $27.6 \%$. About $81.3 \%$ of patients were on OADs ( \pm insulin), 37.7\% were on insulin ( \pm OADs). Majority used biguanides followed by sulfonylureas. Human insulin was used by $73.2 \%$, premix regimen $58.5 \%$, analogues usage was $24.9 \%$. Majority of the WHO-5 well being index responses fell in positive territory.
\end{abstract}




\begin{abstract}
Conclusion: Poor glycaemic control in majority of patients is a concern. There is a need for a large proportion of patients to be adjusted to more intensive pharmacotherapy and a multi-disciplinary approach for management should be adopted. The study findings should be communicated to policymakers and physicians to help them provide proper healthcare and its facilities in Indonesia. (Med J Indones 2010; 19:235-44)
\end{abstract}

Key words: DiabCare, DiabCare Indonesia, Diabetes complications, Dyslipidaemia, Glycaemic control, Hypertension.

Diabetes mellitus is a chronic metabolic disease, which is emerging as a major public health problem. The approach to basic research, management and prevention of diabetes mellitus cannot occur without the results of epidemiological studies. Population studies all over the world have clearly showed that the prevalence of diabetes mellitus (DM) is escalating and prediations indicate a potentially explosive increase in the prevalence of diabetes worldwide, especially in developing countries such as Indonesia. ${ }^{1}$ Worldwide prevalence of diabetes in adults was estimated to be $4.0 \%$ in 1995 and expected to rise to $5.4 \%$ by the year $2025 .{ }^{1}$ The number of adults with diabetes in Indonesia is expected to rise from 6.9 million in 2010 to 12 million in the year $2030 .^{2}$ The incidence of diabetes in the Asian population seems to be on the rise and the incidence of late diabetes complications is also expected to correspondingly increase. This will inevitably impact on society and individuals in Indonesia unless drastic country-wide measures are taken. The health-care and financial costs of the rise in the number of people with diabetes complications are compounded by the psycho-social burden to people with the condition. The heterogeneous ethnicity, races, and ways of lifestyle of the Indonesian population, living in more than 13000 islands, might also be the influencing factors.

The prevalence of urban Indonesia was 5.7\% whereas that of impaired glucose tolerance was $10.2 \% .{ }^{3}$ The prevalence was vary in different region of Indonesia and mostly higher in the urban regions than in the subsequent province. In West Sumatra province, the prevalence of diabetes mellitus was $1.2 \%$ while the highest prevalence was in Sawahlunto city. ${ }^{4}$ In Bali province, the prevalence of diabetes mellitus diagnosed by health care professional and based on symptoms was $1,0 \%$, while in Denpasar city, capital of Bali province, the prevalence was 2, $0 \%{ }^{5}$ The increasing prevalence rate was also found in Ujung Pandang, which showed 1.5 to $5.4 \%$ in urban areas, in Manado showed an exceptionally high prevalence rate of $6.1 \%$ in urban areas. ${ }^{6}$ The prevalence of diabetes in Jakarta was $3.7 \% .^{7}$ There is no data available from Indonesia on the relationship between status of control and prevalence of complications to initiate improvement.

DiabCare study in Indonesia has been conducted in 1997, 1998, 2001, and 2003. ${ }^{8}$ While all these studies evaluated the diabetic management, control and complications status, DiabCare 2003 study was the only one which had Quality of Life evaluation. Also, all previous DiabCare studies except DiabCare 2001 study was carried out involving specialists, 2001 study was carried out involving the primary care physicians. The DiabCare 2008 Indonesia study was initiated to evaluate the disease pattern, its management, control status and complication profile in diabetic population of Indonesia, the association between the physicians' perception of diabetes and current practices, relation between duration of diabetes and diabetes complications, relation between duration of diabetes and quality of life of patient, psychological aspects of patients with diabetes mellitus and identify areas for possible improvements, the association between the patient's perceptions and treatment practices, current status of management of diabetes, its control and complication. This paper presents the outcome of the data collection for the Indonesian diabetes population.

\section{METHODS}

\section{Study design}

The study was carried out in 18 diabetes centers between November 2008 and February 2009. All data were obtained in each diabetes center by reviewing the patients' medical records. Data included information on patient demography, type of diabetes, frequency and nature of educational interventions received, cardiovascular risk factors (blood pressure, lipids, BMI, smoking history and drinking habits), glycaemic control [A1c and fasting blood glucose (FBG)], monitoring of renal function (serum creatinine, microalbuminuria and proteinuria), eye and feet examination in the past 12 months, chronic and severe late complications, diabetes management, and self-monitoring (blood and urine glucose). At each centre the investigator completed a questionnaire designed to capture physicians' perceptions about various aspects of diabetes management. This questionnaire was developed by consensus among the advisory board members after review of a variety of diabetes-related instruments and also previous cross sectional surveys. Psychological well-being of all the patients was assessed adapting WHO-well being Index (WHO-5). Quality of life (QoL) and treatment adherence were measured adopting DAWN survey questions. Patients were also requested to provide response to questions on, quality 
of life and treatment adherence (adapted from five-item WHO well-being Index (WHO-5) and DAWN survey). ${ }^{9}$

\section{Data collection method}

This was a prospective study and data was documented on the DiabCare Asia Case Record Forms (CRFs), which were provided for each patient. Data was obtained from interview and laboratory assessments, as well as clinical examinations as they appeared in patient medical records. Blood samples for A1c measurements were obtained from venous blood EDTA $3 \mathrm{~mL}$ for all patients recruited and analyzed Prodia lab using HPLC method. Instrument used were VARIANT and D 10 for the assay, with the 95\% confidence limit being 4.7-6.4\%. Data field was left blank if no data were available.

\section{Study population}

This study was conducted in 18 centers in Indonesia, which represented the population of Indonesia.These centers were chosen due to the geographical spread, the fact that majority of the diabetic population in Indonesia were treated in secondary and tertiary care hospitals, and the history of previous DiabCare Asia Study (DiabCare 2003). The study population included all patients registered in that clinic center for the management of diabetes for more than 12 months. The diabetes clinic was defined as any clinic that had more than 100 diabetic patients per month. Depending on the type of participating diabetes clinics (restructured hospital or primary health care institutes), the recruitment of patients were carried out in such a way that was representative of the diabetic patient population. About 100 patients were recruited from each participating clinic. Data were obtained from patients visiting each center from November 2008 to February 2009.

\section{Data handling and statistical analysis}

Data were entered into a Statistical Analysis System (SAS, Version 6.12, SAS Institute Inc USA) by electronic scanning and a data entry program was used to validate data quality and generate reports on missing/inconsistent/ invalid data. All data were tabulated and presented as appropriate for the type of data. Data from type 1 patients were not presented due to the small number of patients in each diabetes duration subgroups.

Summary data were presented as mean $\pm \mathrm{SD}$ or a proportion (percentage). Comparisons among groups of study measures were done by t-test, chi-square test, and ANOVA depending on the number of groups and nature of variables. QoL data was analyzed for association using Pearson correlation coefficient. Multiple logistic regressions was performed to compute odds ratio and analyze the relationship of identified predictor (age, sex, physical activity, exercise, duration of diabetes, BMI, BP, cholesterol level, FPG, PPG, HbA1c, LDL and HDL) and outcome (HbAlc and complications). Variable proportion of target achievers of A1c and FPG were also presented as stratified by different targets stipulated by various guidelines (ADA, IDF, EASD and APDPG). ${ }^{10-13}$

\section{RESULTS}

\section{Patient demographic and characteristics}

The total number of patients participated in this study from 18 centers was 1832. Patients from missing or conflicting basic information are excluded from analysis set. The subject characteristics are described in Table 1.

Table 1. Patient Demographic and Characteristics - DiabCare Indonesia 2008 study

\begin{tabular}{|c|c|}
\hline Variable & Data \\
\hline Age $($ Years $) *(n=1719)$ & $58.93 \pm 9.57$ \\
\hline \multicolumn{2}{|l|}{ Gender** $(n=1803)$} \\
\hline Male/ Female & $793(43.3) / 1010(55.16)$ \\
\hline Age at Onset (Years)* $(n=1686)$ & $49.68 \pm 6.8$ \\
\hline Duration of Diabetes (Years)* $(n=1704)$ & $8.61 \pm 5.97$ \\
\hline \multicolumn{2}{|l|}{ Type of Diabetes** } \\
\hline Type 1 & $17(0.9)$ \\
\hline Type 2 & $1785(97.5)$ \\
\hline Others & $2(0.1)$ \\
\hline $\operatorname{BMI}\left(\mathrm{Kg} / \mathrm{m}^{2}\right)^{*}(\mathrm{n}=1646)$ & $25.2 \pm 3.6$ \\
\hline$<23 / 23(\%)$ & $28.7 / 71.3$ \\
\hline Duration of Treatment (Years)* $(n=1817)$ & $8.5 \pm 7.0$ \\
\hline Duration of OADs (Years)* $(n=1727)$ & $8.4 \pm 6.8$ \\
\hline Duration of Insulin (Years) $* *(n=1176)$ & $2.8 \pm 3.0$ \\
\hline Smoking $(\text { Yes })^{* *}(\mathrm{n}=1831)$ & $178(9.7)$ \\
\hline Drinking Alcohol (Yes)** $(n=1831)$ & $24(1.3)$ \\
\hline
\end{tabular}

\section{Glycaemic control}

The mean A1c value was $8.16 \pm 1.99 \%$ and mean FPG was $143.6 \mathrm{mg} / \mathrm{dl}$ (Fig 1). Depending on the criteria applied (IDF/ADA or APDPG), 67-82\% were not on target for Alc and 47-69\% not on target for FPG (Fig. 2). 


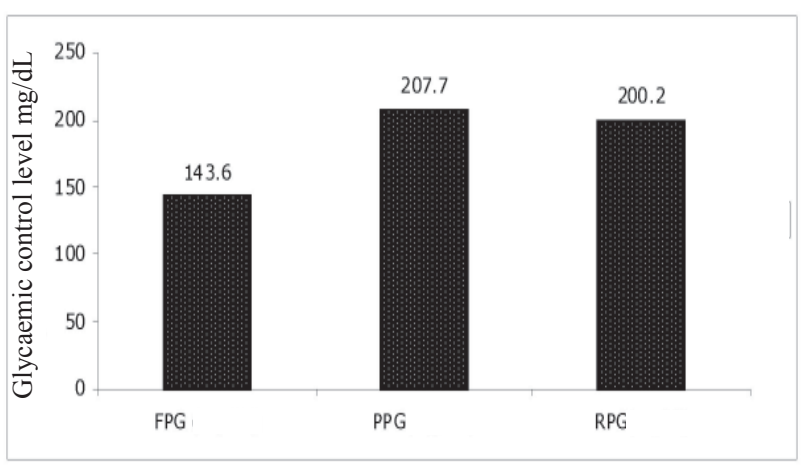

Figure 1. Glycaemic control-DiabCare Indonesia 2008 study
Table 2 shows the comparison of glycaemic control between different diabetes duration among type 2 diabetes patients. With increase in duration of diabetes, both mean A1c and FPG levels were increased except for the first one year of duration of diabetes. For the shorter duration of diabetes ( $1-5$ years), mean A1c and FPG values were $7.7 \pm 1.86 \%$ and $7.6 \pm 2.64 \mathrm{mmol} / \mathrm{l}$, respectively, whereas with longer duration of diabetes ( $>10$ years), mean A1c and FPG values were $8.5 \pm 2.08$ and $8.3 \pm 2.95 \mathrm{mmol} / \mathrm{l}$ respectively. Multiple logistic regression analysis resulted in an OR of $1.41(95 \% \mathrm{CI}$ 1.16 to 1.70 ) for the proportion of target achievers vs. non-achievers with increasing duration of diabetes.

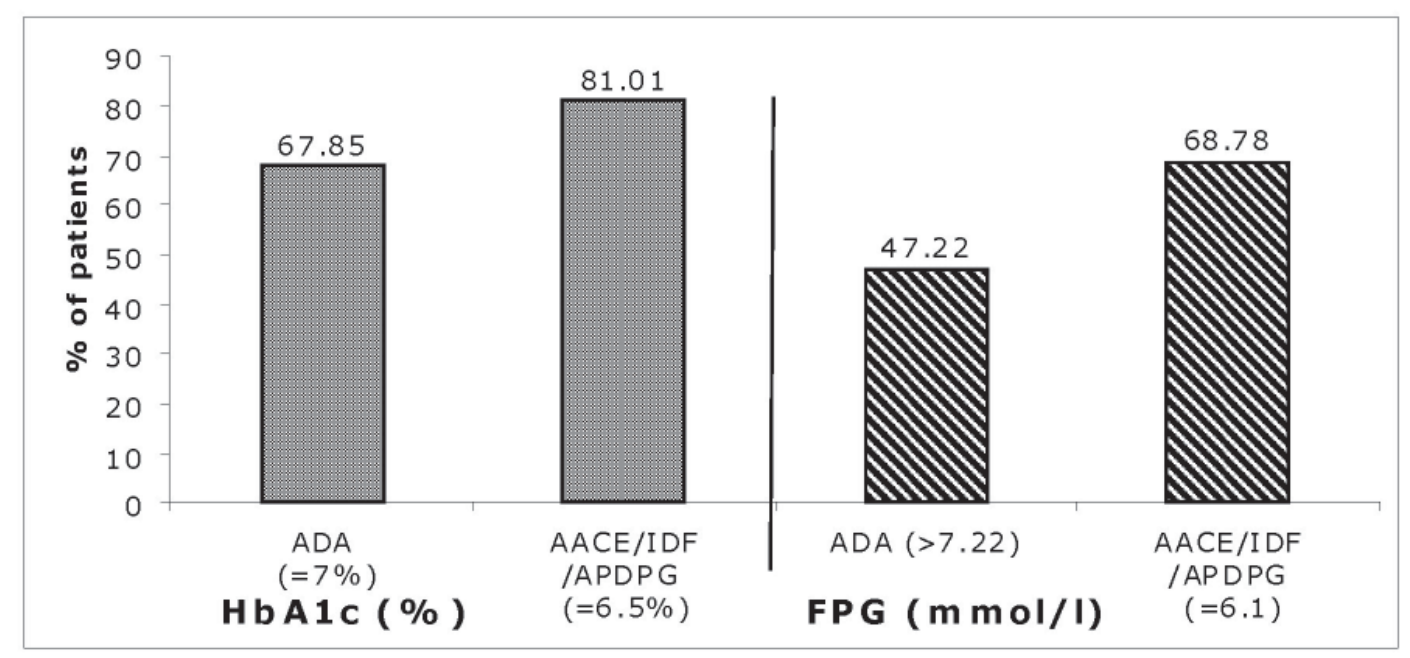

Figure 2. A1c and FPG stratified according to different guidelines

Table 2. Glycaemic Control According to Duration of Diabetes - DiabCare Indonesia 2008 study

\begin{tabular}{|c|c|c|c|c|c|c|c|c|c|}
\hline & \multicolumn{2}{|c|}{$<1$ Year } & \multicolumn{2}{|c|}{$1-5$ Years } & \multicolumn{2}{|c|}{$>5$ - 10 Years } & \multicolumn{2}{|c|}{$>10$ Years } & \multirow{2}{*}{$\mathrm{P}$} \\
\hline & $\mathrm{N}$ & Mean \pm SD & $\mathrm{N}$ & Mean \pm SD & $\mathrm{N}$ & Mean \pm SD & $\mathrm{N}$ & Mean \pm SD & \\
\hline A1c (\%) & 44 & $7.8 \pm 1.70$ & 545 & $7.7 \pm 1.86$ & 450 & $8.4 \pm 2.03$ & 563 & $8.5 \pm 2.08$ & $<0.0001$ \\
\hline FPG (mg/dL) & 42 & $138.6 \pm 46.6$ & 521 & $136.8 \pm 47.5$ & 397 & $145.8 \pm 51.1$ & 502 & $149.4 \pm 53.1$ & $<0.0001$ \\
\hline PPG (mg/dL) & 43 & $198 \pm 75.6$ & 490 & $198 \pm 80.8$ & 377 & $214.2 \pm 85$ & 460 & $216 \pm 80.6$ & 0.003 \\
\hline RBG (mg/dL) & 10 & $181.8 \pm 61.9$ & 129 & $192.6 \pm 77.9$ & 97 & $198 \pm 72.9$ & 164 & $208.8 \pm 81$ & 0.322 \\
\hline
\end{tabular}

\section{Lipid Control}

The fasting lipid profile of diabetes patients are shown in Table 3. Lipid measurements were done for about $76 \%$ $(1390 / 1832)$ of patients. Dyslipidemia was reported in $60 \%(834 / 1390)$ of patients for whom lipid measurements were done. $74 \%(617 / 834)$ of patients with dyslipidemia have received lipid lowering treatment. When stratified according to duration of diabetes, the number of patients treated for dyslipidemia increased with duration of diabetes significantly $(p<0.0001)$. Among those who received treatment for dyslipidemia, almost all patients received statins with a few $(7.2 \%)$ on fibrates. 
Table 3: Lipid profile - DiabCare Indonesia 2008 study

\begin{tabular}{|c|c|c|c|c|c|c|c|c|c|c|}
\hline & \multicolumn{9}{|c|}{ DURATION OF DIABETES } & \multirow[b]{2}{*}{$\mathbf{P}$} \\
\hline & \multicolumn{2}{|l|}{ Overall } & $<1$ Year & \multicolumn{2}{|c|}{1 - 5 Years } & \multicolumn{2}{|c|}{$>5$ - 10 Years } & \multicolumn{2}{|c|}{$>10$ Years } & \\
\hline & Mean \pm SD & $\mathrm{N}$ & Mean \pm SD & $\mathrm{N}$ & Mean \pm SD & $\mathrm{N}$ & Mean \pm SD & $\mathrm{N}$ & Mean \pm SD & \\
\hline LDL(mg/dL) & $130.7 \pm 41.3$ & 26 & $124.8 \pm 43.3$ & 384 & $132.6 \pm 41.7$ & 319 & $136.5 \pm 43.7$ & 445 & $128.7 \pm 41.3$ & NS \\
\hline HDL(mg/dL) & $50.7 \pm 31.2$ & 25 & $50.7 \pm 23.8$ & 379 & $50.7 \pm 42.1$ & 311 & $50.7 \pm 17.6$ & 425 & $50.7 \pm 30.8$ & NS \\
\hline Triglycerides (mg/dL) & $149.5 \pm 105$ & 27 & $142.4 \pm 99.7$ & 394 & $151.3 \pm 82.8$ & 332 & $160.2 \pm 90.8$ & 441 & $151.3 \pm 93.5$ & NS \\
\hline
\end{tabular}

\section{Diabetes Complications}

In this study $57.8 \%(1031 / 1785)$ were evaluated for diabetic complications. The split of proportion evaluated for individual complication is as followsDiabetic retinopathy $(42 \%, 760 / 1785)$, nephropathy $7.3 \%$ (131/1785), neuropathy 63.5\% (1133/1785), severe late complications $16.9 \% \quad(302 / 1785)$, macrovascular complications $16.0 \%(285 / 1785)$, microvascular complications $27.6 \%$ (493/1785). All diabetic complications are presented in Table 4. Amongst eye complications, cataract was $(27,6$ 493/1785) most commonly reported eye complication followed by non-proliferative retinopathy $(18.97 \%$ 338/1785). Cataract ( $\mathrm{p}<0.001)$ and non-proliferative retinopathy $(\mathrm{p}<0.01)$ increased significantly with duration of diabetes.

Table 4: Diabetic Complications Stratified According to Duration of Diabetes - DiabCare Indonesia 2008

\begin{tabular}{|c|c|c|c|c|c|}
\hline \multirow[b]{2}{*}{ Complications } & \multicolumn{4}{|c|}{ Duration of Diabetes } & \multirow[b]{2}{*}{$>10$} \\
\hline & Overall $^{\#}$ & $<1$ & $1-5$ & $>5-<10$ & \\
\hline $\mathrm{N}$ & 1785 & 15 & 612 & 432 & 645 \\
\hline \multicolumn{6}{|l|}{ Eye Complications, n (\%) } \\
\hline Cataract & $259(14.5)$ & $0(0)$ & $59(9.6)$ & $56(13.0)$ & $127(19.7)^{*}$ \\
\hline Non-proliferative -retinopathy & $148(8.3)$ & $1(6.7)$ & $30(4.9)$ & $28(6.5)$ & $76(11.8)$ \\
\hline Proliferative retinopathy & $33(1.8)$ & $0(0)$ & $7(1.1)$ & $5(1.2)$ & $15(2.3)^{*}$ \\
\hline Advanced eye disease & $9(0.5)$ & $0(0)$ & $2(0.3)$ & $0(0)$ & $6(0.9)$ \\
\hline Photocoagulation & $18(1.0)$ & $0(0)$ & $4(0.7)$ & $3(0.7)$ & $10(1.6)$ \\
\hline Legal Blindness & $6(0.3)$ & $0(0)$ & $0(0)$ & $2(0.5)$ & $4(0.6)$ \\
\hline \multicolumn{6}{|l|}{ Diabetic nephropathy, n (\%) } \\
\hline Serum creatinine $>2 \mathrm{mg} / \mathrm{dl}$ & $65(3.6)$ & $0(0)$ & $11(1.8)$ & $11(2.5)$ & $37(5.7)^{*}$ \\
\hline Microalbuminuria & $64(3.6)$ & $0(0)$ & $16(2.6)$ & $16(3.7)$ & $31(4.8)$ \\
\hline Macroalbuminuria & $18(1.0)$ & $0(0)$ & $2(0.3)$ & $7(1.6)$ & $9(1.4)$ \\
\hline \multicolumn{6}{|l|}{ Foot Complications, n (\%) } \\
\hline Absent foot pulse & $27(1.3)$ & $0(0)$ & $6(1.0)$ & $7(1.6)$ & $13(2.0)$ \\
\hline Healed ulcer & $68(3.8)$ & $1(6.7)$ & $9(1.5)$ & $18(4.2)$ & $36(5.6)^{*}$ \\
\hline Active ulcer gangrene & $18(1.0)$ & $0(0)$ & $3(0.5)$ & $3(0.7)$ & $12(1.9)$ \\
\hline Leg amputation & $12(0.7)$ & $0(0)$ & $4(0.6)$ & $4(0.9)$ & $4(0.6)$ \\
\hline \multicolumn{6}{|c|}{ Cardiovascular Complications, n (\%) } \\
\hline Angina pectoris & $28(1.6)$ & $0(0)$ & $5(0.8)$ & $2(0.5)$ & $20(3.1)$ \\
\hline Myocardial infarction & $176(9.9)$ & $1(6.7)$ & $41(6.7)$ & $42(9.7)$ & $81(12.6)$ \\
\hline Stroke & $98(5.5)$ & $0(0)$ & $27(4.4)$ & $22(5.1)$ & $42(6.5)$ \\
\hline Angioplasty/ CABG & $100(5.6)$ & $1(6.7)$ & $31(5.1)$ & $17(3.9)$ & $45(7.0)$ \\
\hline \multicolumn{6}{|l|}{ Other complications: } \\
\hline Erectile Dysfunction & $153(8.6)$ & $0(0)$ & $29(4.7)$ & $36(8.3)$ & $75(11.6)$ \\
\hline
\end{tabular}

$* \mathrm{p}<0.05$; \# Percentages for "Overall" are calculated out of 1785; Percentage of complications for duration categories are calculated out of "N" for the respective category; CABG, Coronary Artery Bypass Grafting 
Renal function was evaluated by testing for microalbuminuria $(14.25 ; 262 / 1785)$ and serum creatinine $(73.9 \%$; $1317 / 1785$ ). Among those tested for microalbuminuria, $24.14 \%(63 / 262)$ had microalbuminuria $(30-300 \mathrm{mg} / \mathrm{l}$ excreated albumin), $6.52 \%$ (17/262) had macroalbuminuria ( $>300 \mathrm{mg} / \mathrm{dL} / 24 \mathrm{~h}$ excreted protein).The number of patients with serum creatinine $>180 \mu \mathrm{mol} / \mathrm{l}$ increased significantly $(p=0.001)$ with duration of diabetes.

Symptoms of neuropathy were observed in $67.17 \%$ (671/1133) of patients evaluated for neuropathy. Microfilament test was performed for a small group of patients (1.32\% 15/1131) and ankle jerk was absent in $67.67 \%(767 / 1133)$ of patients tested for neuropathy.

Amongst foot complications, the frequencies of healed ulcer $(p<0.001)$ and angioplasty $(p<0.01)$ increased significantly with increase in duration of diabetes CAD (10.1\% 166/1785), erectile dysfunction (8.9\% 161/1785) and cerebral stroke $(5.63 \% 101 / 1785)$ were reported as late complications and the proportion of patients with $\mathrm{CAD}$ and erectile dysfunction increased with duration of diabetes from 6.67 to $12.84 \%(p<0.01)$ and 5.03 to $12.99 \%(p=N S)$ respectively (Table 4$)$. Based on reported systolic blood pressure (SBP), diastolic blood pressure (DBP) and whether patients required medication for hypertension, 59.4\% (1060/1785) could be considered as having co-existing hypertension. Amongst these 56.5\% (599/1060) were on medication, most of them on ACE inhibitor $(55.18 \%, 559 / 1013)$ followed by $\mathrm{Ca}^{2+}$ channel antagonists $(37.91 \%, 384 / 1013)$ and angiotensin receptor blockers (ARB) $(27.44 \%, 278 / 1013)$ and others.

Increasing duration of diabetes was generally associated with more complications. This attained statistical significance with cataract $(\mathrm{OR}=1.33 ; 95 \%$ CI 1.03 to 1.70), proliferative retinopathy $(\mathrm{OR}=1.99 ; 95 \% \mathrm{CI} 1.06$ to 3.71 ), healed ulcer ( $\mathrm{OR}=1.63 ; 95 \% \mathrm{CL} 1.04$ to 2.55$)$, and $\mathrm{CAD}(\mathrm{OR}=1.40 ; 95 \% \mathrm{CI} 1.07$ to 1.83$)$.

\section{Management}

As shown in Table-5, 81.32\% (1489/1785) of patients were on OADs ( \pm insulin), 37.7\% (673/1785) were on insulin ( \pm OADs). Amongst OADs users, majority used biaguanides followed by sulfonylureas and alpha glucosidase inhibitors. For single OAD treatment, biaguanides or sulfonylureas were first choice. Among the insulin users, majority was using human insulin $(73.2 \%$, 493/673) and premix insulin (58.5\% 394/673). Analogues were used by $24.9 \%$ (168/673) of patients only.

Based on the data available on glucose self monitoring, only $22.16 \%(396 / 1785)$ of patients practiced any form of self-monitoring. The mean frequency of selfmonitoring was $4.96 \pm 6.66$ times per month.

Table 5. Diabetes Management- DiabCare Indonesia 2008

\begin{tabular}{ll}
\hline Diabetes management variable & Data, n (\%) \\
\hline Type of Management & \\
Diet & $317(17.31)$ \\
Insulin monotherapy & $356(19.44)$ \\
Insulin and OAD combination & $1133(61.88)$ \\
OAD monotherapy & $5(0.27)$ \\
Herbal & $20(1.09)$ \\
None & \\
\hline Type of OAD Therapy & $1085(59.26)$ \\
Biguanides & $1036(56.58)$ \\
Sulphonylureas & $8(0.44)$ \\
Meglitinides & $461(25.18)$ \\
Alpha Glucosidase inhibitors & $51(2.79)$ \\
Thiazolidinediones & $48(2.62)$ \\
Other OADs & $5(0.27)$ \\
Traditional Herbal medicines & $88(4.81)$ \\
Double drug fixed dose combination & $5(0.27)$ \\
Triple drug fixed dose combination & \\
\hline Insulin therapy (N=666) & $37.81 \pm 8.2$ \\
Units/day, (mean \pm SD) & $126(18.91)$ \\
Once daily & $371(55.71)$ \\
Twice daily & $167(25.08)$ \\
More than twice daily & \\
\hline Mode of insulin administration $(\mathrm{N}=666)$ & $631(94.75)$ \\
Pen & $18(2.70)$ \\
Syringe & $19(2.85)$ \\
Pump & $11(0.7)$ \\
\hline Other treatments & $476(29.1)$ \\
Anti obesity drug & $775(47.7)$ \\
Anti platelet drugs & \\
Aspirin & \\
\hline
\end{tabular}

As per the available data among the insulin users, majority of them were using insulin injections twice daily $(n=371$; $55.71 \%$ ) followed by those using more than twice daily $(\mathrm{n}=167 ; 25.08 \%)$ and once daily $(\mathrm{n}=126 ; 18.91 \%)$. Most of the insulin users were using insulin pen $(n=631$; $94.75 \%)$. The insulin dose increased with the duration of diabetes $(\mathrm{p}=0.001)$ and it was observed that the OAD use decreased among the patients having diabetes more than 10 years. Few patients $(0.7 \% ; 12 / 1785)$ were taking anti obesity treatment. Anti platelet drugs were used by $29.1 \%(520 / 1785)$ of patients, almost all on aspirin.

\section{Psychological well-being, QoL and treatment adherence}

Most responses from patients fell in positive impact territory in WHO-5 well being index as shown in Figure 3. The psychological well-being scores correlated positively and significantly $(\mathrm{p}<0.01)$ with glycaemic control. 


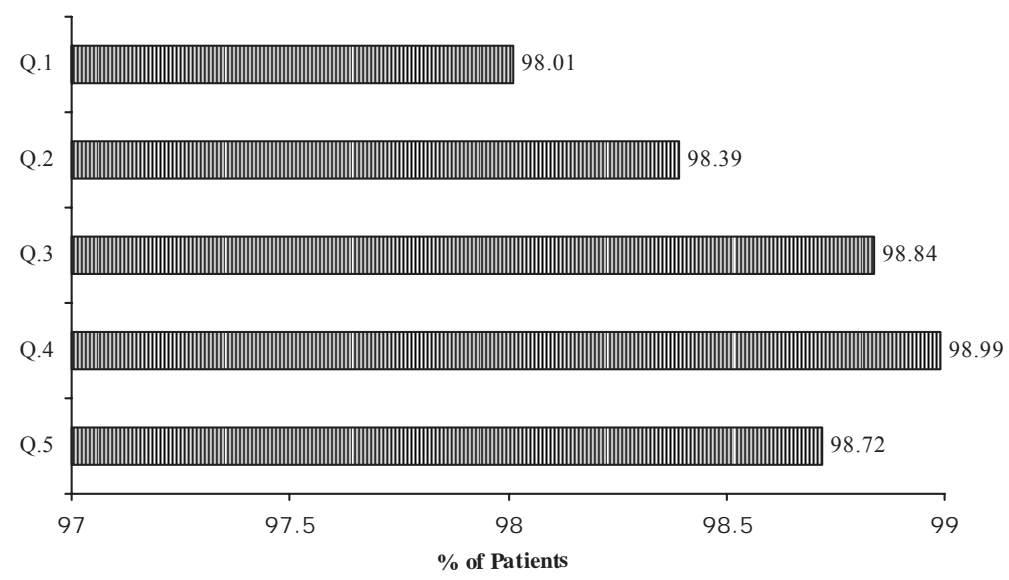

Q.1, Daily lives filled with things that interest me; Q.2, Woke up feeling fresh \& rested; Q.3, Active and vigorous; Q.4, Calm and relaxed; Q.5, Cheerful \& good spirits.

Figure 3. Cumulative proportion of patients that scored well on the WHO-5 well being index DiabCare Indonesia 2008 study

Majority of patients responded positively on their quality of life (QoL) as presented in Figure 4. In addition to these questions, patients who were not using insulin were asked to provide responses to two questions 1 . "I am very worried having to start on insulin" (38.6\% agreed) 2.starting on insulin would mean I have not followed my treatment recommendation properly (39.5\% agreed).
Almost all the patients responded that they adhere to taking prescribed medication $(99.1 \%, 1769 / 1785)$, adhere to exercise $(99.3 \% 1773 / 1785)$ and adherence to $\operatorname{diet}(95.9 \%, 1712 / 1785)$.

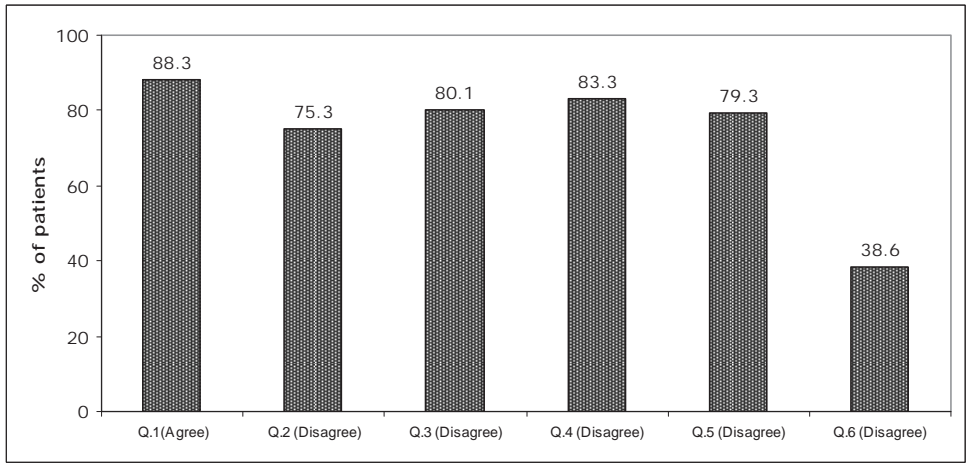

Q.1, My diabetes is well regulated; Q.2, I am tired of complying with taking diabetes medications; Q.3, I feel burned out from coping with diabetes; Q.4, I feel Diabetes is preventing me from doing what I want to do; Q.5, Coping with diabetes is more difficult now; Q.6, I am worried about having to start insulin. Responses are taken as total of Mainly/ Fully agree/ disagree.

Figure 4: Quality of Life - DiabCare Indonesia 2008 study

\section{Physicians' perceptions}

All 18 physicians responded to the physician questionnaire. There were many key results. When asked 'do you advice A1c estimation of every patients of yours', almost all $(94.44 \%, 17 / 18)$ the physicians preferred to do it. $65 \%(12 / 18)$ of physicians responded that they would test A1c 4 times a year for patients who are uncontrolled (A1c > 7\%), 72\% (13/18) of physicians feel that less than $40 \%$ of their patients are under A1c of $<7$. Majority of physicians $(77 \% 14 / 18)$ feel that 2 OAD combinations are justified. The use of analogues insulin for better glycaemic control was advocated by almost all (94.44\% 17/18) of physicians and self monitoring of blood sugar and the use of modern insulin delivery 
devices like insulin pens were also supported by all the physicians.

\section{DISCUSSIONS}

The DiabCare Asia project was initiated to study the status of diabetes care and prevalence of diabetic complications in Asia. This study was conducted in different countries in Asia from 1995. Indonesia participated in this study for the first time in 1998 and later in $2003 .{ }^{15}$ The results pertaining to 2003 DiabCare Indonesia were not published; however included here for the purpose of discussion. ${ }^{16}$

Table 6. Comparison of DiabCare 2003 and 2008 studies

\begin{tabular}{lcc}
\hline Parameter & DiabCare 2003* & DiabCare 2008 \\
\hline Age (Yrs) & $58.7 \pm 9.3$ & $58.9 \pm 9.5$ \\
Duration of diabetes (Yrs) & $9.2 \pm 6.6$ & $9.2 \pm 7.2$ \\
Sex (M/F) \% & $42.9 / 57.1$ & $44 / 56$ \\
Type 2 DM (\%) & 98.2 & 97.4 \\
Mean BMI (kg/m2) & $24.1 \pm 3.5$ & $25.1 \pm 3.6$ \\
Mean A1c (\%) & $7.9 \pm 2.0$ & $8.1 \pm 1.6$ \\
Mean FPG (mmol/l) & $8.4 \pm 3.4$ & $7.9 \pm 2.4$ \\
Mean PPG (mmol/l) & $11.6 \pm 3.9$ & $11.5 \pm 3.6$ \\
HDL-cholesterol (mmol/1) & $1.3 \pm 0.4$ & $1.3 \pm 0.8$ \\
Triglycerides (mmol/l) & $2.0 \pm 1.1$ & $1.7 \pm 0.6$ \\
\hline
\end{tabular}

* Data on file, Novo Nordisk

Relative comparison of 2008 and 2003 DiabCare results show that the baseline and demographic characteristics almost remained the same. In both study cohorts, there was a slight preponderance of females to males (1.27:1 in the present study versus 1.3:1 in the 2003 study cohort). In the current study, many patients $(77.35 \%)$ were diagnosed as obese $\left(\mathrm{BMI}>23 \mathrm{~kg} / \mathrm{m}^{2}\right) .{ }^{14}$

The Mean A1c was slightly higher in 2008 than 2003, and when the patients are categorised according to APDPG guidelines (A1c $<6.5$ is optimal), there was a higher proportion $(25.8 \%)$ of target achievers in 2003 vs. $2008(18.91 \%)$. The level of glycaemic control in this study is less than satisfactory despite the fact that all patients are on OADs. However, achieving good glycaemic control, according to the ADA, or IDF or APDPG guidelines was difficult. ${ }^{10,11,13}$ The QuED study outcome showed that the risk of poor glycaemic control (A1c > 7.0\%) correlated highly with physicians' own patient assessments. ${ }^{17}$ In type 2 diabetes, the lack of appreciation of the progressive decline of the betacell function, the avoidance of poly-pharmacy/insulin treatment, the fear of hypoglycaemia and of exacerbating weight gain, as well as unfounded fears over the possibility of increased macrovascular risk with insulin therapy can all contribute to the problem of sub-optimal glycaemic control. ${ }^{18} \mathrm{~A}$ multi-disciplinary approach is needed to achieve glycaemic target. Newly-diagnosed individuals should be treated intensively with the aim of achieving A1c $<6.5 \%$ within 6 months of diagnosis. For those who are not at goal after three months, combination therapy should be considered in order to reach the 6-month goal. For individuals who have particularly high blood glucose at diagnosis (A1c $\geq 9 \%$ ), consideration should be given to initiating combination therapy immediately, and/or use of insulin therapy (before transfer to monoor combination oral therapy) in order to reduce glucose toxicity and reach glycaemic goals as soon as possible.

In the present study, there was an increasing trend in values for FPG, insulin users, insulin dose, and duration of treatment with duration of diabetes. In spite of increase in number of patients on insulin with the increase in duration of diabetes, the FPG remained high. This indicates there is a need for intensifying the insulin therapy by the physicians.

Serum creatinine was performed for majority $(73.9 \%$ $1320 / 1785$ ) of patients and microalbuminuria test was performed for $14.25 \%$ of patients, The American Diabetes Association (ADA) and the National Institutes of Health (NIH) recommend the annual assessment of urine albumine and also the estimation of glomerular filtration rate (eGFR) from serum creatinine at least once a year in all people with diabetes. eGFR and urine albumin are key markers of diabetic kidney disease. ${ }^{19}$

Data on other diabetic complications showed that neuropathy $(67.2 \%)$ was the most common complication. Since diabetic neuropathy has been reported to increase the risk for other complications including leg amputations and foot ulcers, screening programs to diagnose diabetic neuropathy should be performed on a regular basis. ${ }^{20}$ This may be due to inadequate facilities at some hospitals as well as due to increase in number of patients with neuropathy so that there is very less time for physicians to evaluate all diabetic patients for neuropathy.

The mean duration of diabetes, duration of OAD treatment and duration of insulin treatment are 9.25, 8.40 and 2.77 years respectively (Table 1.) Insulin therapy is shorter when compared to total treatment duration for diabetes in this study and it was also observed that majority of patients' A1c is above target 
according to all other guidelines. The poor glycaemic control, large proportion of patients on OADs only and delayed initiation of insulin therapy, may lead to development of long term diabetic complications. The United Kingdom Prospective Diabetes Studies (UKPDS) showed that about $50 \%$ of type 2 patients on prior OADs failed to achieve glycaemic control required insulin treatment to maintain control of glycaemia about 6 years after diagnosis. ${ }^{21}$ Since QoL was improved when insulin was initiated in a group of patients with favourable QoL scores, insulin initiation should not be delayed until oral agents fail to maintain adequate glycaemic control. ${ }^{22}$

In the present study, majority of patients rated their quality of life to be good or at least acceptable. Quality of life is an important health outcome, representing the ultimate goal of all health interventions. People with diabetes often feel challenged by their disease and its daily management demands. In the present study QoL (DAWN) scores inversely correlated with glycaemic parameters.

One of the objectives of this study was to describe physicians' attitudes toward diabetes care. This study highlights the challenges physicians face between managing diabetes while coping with the realities. The data indicate that there is a gap between the frequencies of A1c test recommended by the physicians versus real life practice. This gap may be filled by creating awareness on disease progression and related complications. Majority of physicians agreed with the goals of good glycemic control and preventing complications. Moreover, almost all physicians believed that analogues improve glycaemic control and advocated self monitoring of blood glucose and use of modern insulin devices like insulin pens.

In conclusion, the findings of this retrospective-prospective cross sectional study on Indonesian patients suggests that Glycaemic control in type 2 diabetic patients is below the stipulated guidelines. The poor glycemic control is reflected in the number of complications observed. To reduce the risk of diabetes-associated complications, glycaemia needs to be maintained at a satisfactory level and earlier detection of the disease should be part of the strategy There is a need for a large proportion of patients to be adjusted to more intensive pharmacotherapy, to delay the disease progression, and achieving the ultimate goal of preventing the development of late onset complications. This can be achieved by strengthening the multi-disciplinary approach and stressing on the pillars of diabetes management : Lifestyle changes, patient education, appropriate pharmacotherapy and self-testing, to manage diabetes mellitus.
Indeed, on the subject of intensive pharmacotherapy, the UKPDS study showed that almost all patients will require multiple oral agents to achieve desired glycaemic targets, and in a large proportion of patients, insulin therapy will be necessary. ${ }^{23}$ Since most of the patients were diagnosed for their diabetes in a later stage (not as the UKPDS subjects), early insulin initiation and intensification are needed to delay the progress of type 2 diabetes, to prevent its complications, to alleviate the burden on healthcare systems and to improve patient quality of life in Indonesia.

\section{Acknowledgment}

DiabCare-Indonesia 2008 was supported by PT Novo Nordisk Indonesia. The authors acknowledge the contributions of all investigative sites as listed below.

The authors thank Dr. M V Srishyla, Dr. Anand Jain Dr. B S Mohan, and Dr. Luki of Novo Nordisk (ROFE) for their valuable contributions to the study and data analysis medical writing and review. The assistance of Prof NSN Rao from Institute of Health Management and Research, Bangalore in statistical analysis of data is gratefully acknowledged.

\section{REFERENCES}

1. SutanegaraD,Darmono,BudhiaarthaAAG.Theepidemiology, and management of diabetes mellitus in Indonesia. Diabetes Research and Clinical Practice. 2000;50: S9-S16

2. IDF Diabetes Atlas, 4 th ed.CInternational Diabetes Federation, 2009.

3. Mihardja L, Delima, Siswoyo H, Ghani L, Soegondo S. Prevalence and Determinants of Diabetes Mellitus and Impaired Glucose Tolerance in Indonesia (A Part of Basic Health Research/Riskesdas). Acta Med Indones-Indones J Intern Med. 2009:41:169-74.

4. RISKESDAS SUMATERA BARAT 2007, Basic Health Research of West Sumatera Province, Indonesian Ministry of Health, Health Research and Development Body, 2008.

5. RISKESDAS BALI 2007, Basic Health Research of Bali Province 2007, Indonesian Ministry of Health, Health Research and Development Body, 2008.

6. Perkeni. Konsensus Pengelolaan Diabetes di Indonesia; 2006.

7. Harbuwono DK, Purnamasari D, Soegondo S, Edi TJ, Em YB, Soebardi S, et al. Prevalence of Diabetes Mellitus in Jakarta. AASD Poster Presentation; II-P-41. 2009 May 22; Osaka, Japan

8. World Health Organization: Regional Office for Europe (1998) Well-Being measures in primary health care: The DiabCare Project. Consensus meeting, Stockholm

9. Skovlund SE, Peyrot M, on behalf of the DAWN International Advisory Panel.The Diabetes Attitudes, Wishes, and Needs (DAWN) Program: A New Approach to Improving Outcomes of Diabetes Care. 2005; 18:136-42 
10. Asia-Pacific Type 2 Diabetes Policy Group. Type 2 Diabetes -Practical Targets and Treatments, 2nd edn. Sydney, Australia: Health Communications Australia Pty, 1999.

11. American Diabetes Association. Standards of medical care for patients with diabetes mellitus. Diabetes Care 2000;23:S32-S42.

12. Ryde'L, Standl E, Bartnik M, Van den Berghe G, Betteridge $\mathrm{J}$ et al, The Task Force on Diabetes and Cardiovascular Diseases of the European Society of Cardiology (ESC) and of the European Association for the Study of Diabetes (EASD). Guidelines on diabetes, pre-diabetes, and cardiovascular diseases: executive summary. Eur Heart J. 2007;28:88-136.

13. IDF Global Guideline for Type 2 Diabetes, 2005

14. WHO expert consultation. Lancet. 2004;363:157-63

15. Mafauzy M on Behalf of the Diabcare-Asia 2003 Study Group. An audit on diabetes management in Asian patients treated by specialists: the Diabcare-Asia 1998 and 2003 studies. Curr Med Res Opin. 2008; 24: 507-14.

16. Data on file, Novo Nordisk, 2003.

17. The QuED Study Group. The relationship between physicians'self-reported target fasting blood glucose levels and metabolic control in type 2 diabetes. The QuED Study
Group - quality of care and outcomes in type 2 diabetes. Diabetes Care.2001;24:423-9

18. Wallace TM, and Matthews DR. Tha assessment of insulin resistance in man. Diabet Med. 2002; 19: 527-534.

19. NIH Publication No. 08-6286; May 2008

20. Lehto S, Rönnemaa T, Pyörälä K, Laakso M. Predictors of Stroke in Middle-Aged Patients With Non-InsulinDependent Diabetes. Stroke. 1996; 27: 63-8.

21. UK Prospective Diabetes Study (UKPDS) Group. Intensive blood-glucose control with sulphonylureas or insulin compared with conventional treatment and risk of complications in patients with type 2 diabetes (UKPDS 33). Lancet 1998; 352:837-53.

22. Ashwell S, Bradley C, Stephens JW, Witthaus E and Home P. Treatment satisfaction and quality of life with insulin glargine and insulin lispro compared with NPH insulin plus unmodified human insulin in individuals with Type 1 diabetes. Diabetes care 2008;31:1112-7

23. Turner RC, Cull CA, Frighi V et al. Glycemic control with diet, sulfonylurea, metformin, or insulin in patients with type 2 diabetes mellitus: progressive requirement for multiple therapies (UKPDS 49). JAMA 1999; 281:2005-12. 